\begin{tabular}{|l|c|c|c|c|}
\hline $\begin{array}{l}\text { Cuadernos de Investigación Geográfica } \\
\text { Geographical Research Letters }\end{array}$ & 2020 & N $^{\circ} 46(1)$ & pp.59-79 & eISSN 1697-9540 \\
\hline
\end{tabular}

DOI: http://doi.org/10.18172/cig.3801

(C) Universidad de La Rioja

\title{
GENERATION OF DAILY HIGH-SPATIAL RESOLUTION SNOW DEPTH MAPS FROM IN-SITU MEASUREMENT AND TIME-LAPSE PHOTOGRAPHS ${ }^{1}$
}

\author{
J. REVUELTO ${ }^{1,2 *}$, E. ALONSO-GONZÁLEZ ${ }^{1}$, J.I. LÓPEZ-MORENO ${ }^{1}$ \\ ${ }^{1}$ Instituto Pirenaico de Ecología, Consejo Superior de Investigaciones Científicas (IPE-CSIC), \\ Zaragoza, Spain \\ ${ }^{2}$ Université Grenoble Alpes, Université de Toulouse, Météo-France-CNRS, \\ CNRM, Centre d'Etudes de la Neige, 38000 Grenoble, France.
}

\begin{abstract}
Acquiring information on snow depth distribution at high spatial and temporal resolution in mountain areas is time consuming and generally these acquisitions are subjected to meteorological constrains. This work presents a simple approach to assess snow depth distribution from automatically observed snow variables and a pre-existing database of snow depth maps. By combining daily observations of in-situ snow depth, georectified time-lapse photography (snow presence or absence) and information on snowpack distribution during annual snow peaks determined with a Terrestrial Laser Scanner (TLS), a method was developed to simulate snow depth distribution on day-by-day basis. This method was tested is Izas Experimental Catchment, in the Central Spanish Pyrenees, a site with a large database of TLS observations, time-lapse images and nivo-meteorological variables for six snow seasons (from 2011 to 2017). The contrasted snow climatic characteristics among the snow seasons allowed analysis of the transferability of snowpack distribution patterns observed during particular seasons to periods without spatialized snow depth observations, by TLS or other procedures. The method i) determines snow depth ratio among the observed maximum snow depths and all other snow map pixels at the TLS yearly snow peak accumulation, $i i$ ) rescales these ratios on a daily basis with time-lapse images information and iii) calculates the snow depth distribution with; the rescaled ratios and the snow depth observed at the automatic weather station. The average of the six TLS observed peaks was the combination showing optimal overall applicability. Despite its simplicity, these simulated values showed encouraging results when compared with snow depth distribution observed on particular dates. This was due primarily to the strong
\end{abstract}

1 This paper has received the Second Prize from the Young Researcher Innovation Award on Cryosphere Science, granted by the Research Group on Physical Geography in High Mountains, Complutense University of Madrid (Department of Geography), Spain. 
topographic control of small scale snow depth distribution on heterogeneous mountain areas, which has high inter-and intra-annual consistencies.

Generación de mapas diarios de espesor de nieve a alta resolución espacial a partir de observaciones puntuales y fotografías automáticas diarias (time-lapse)

RESUMEN. En zonas de montaña, la adquisición de información distribuida del manto de nieve a elevada resolución espacio-temporal es muy laboriosa y además se ve limitado por las condiciones ambientales. Este trabajo presenta una metodología sencilla para generar mapas diarios de espesor de nieve combinando observaciones automáticas in-situ con una base de datos pre-existente de mapas de espesor de nieve. Las observaciones automáticas las constituyen datos diarios de espesor de nieve en un punto conocido (estación meteorológica) y fotografías time-lapse georectificadas de la superficie cubierta por nieve. La base de datos pre-existente, la conforman mapas de espesor de nieve obtenidos en el pico de acumulación de nieve anual generados con un Láser Escáner Terrestre (TLS). La zona de estudio en la que se ha validado esta metodología es la Cuenca Experimental de Izas en los Pirineos Centrales Españoles, cuenca en la que existen un total de seis temporadas hibernales (2011-2017) con las observaciones TLS así como con las variables nivo-meteorológicas necesarias para simular la distribución diaria del espesor de nieve. Las contrastadas características climáticas de las seis temporadas disponibles, permite analizar la posibilidad de emplear patrones de distribución de nieve observados una temporada en particular para simular la distribución en periodos sin observaciones distribuida (TLS u otros métodos). La mitología i) determina para las observaciones TLS en el pico de acumulación el ratio entre el valor máximo de espesor de nieve y los valores observados en el resto de pixeles, ii) re-escala diariamente dichos ratios para las zonas cubiertas por nieve a partir de la información de las fotografías time-lapse y iii) calcular la distribución de nieve con los ratios re-escalados y la observación diaria de espesor en nieve en la estación meteorológica. El promedio de los seis picos de acumulación observados con el TLS ha resultado ser la combinación que ha obtenido los mejores resultados. Pese a la simplicidad de esta metodología, los valores simulados han demostrado resultados alentadores cuando han sido comparados con observaciones de espesor de nieve en fechas particulares. Esto es debido principalmente al importante control que ejerce la topografía en la distribución del manto de nieve a pequeña escala en zonas heterogéneas de montaña, la cual tiene una elevada consistencia inter e intra-anual.

Key words: Snowpack distribution, mountain areas, time-lapse photography, terrestrial laser scanner.

Palabras clave: distribución del manto de nieve, áreas de montaña, fotografía time-lapse, láser escáner terrestre.

Received: 30 October 2018

Accepted: 10 April 2019 
*Corresponding author: Jesús Revuelto, Instituto Pirenaico de Ecología, Consejo Superior de Investigaciones Científicas (IPE-CSIC), Campus de Aula Dei, P.O. Box 13.034, 50.080-Zaragoza, Spain. E-mail address: jrevuelto@ipe.csic.es

\section{Introduction}

Observing, studying and understanding the temporal changes in snow depth distribution in mountain areas is significant for various environmental and socioeconomic issues. Spatio-temporal changes in snowpack depth are directly associated with plant survival (Wipf et al., 2009), erosion rates (Pomeroy and Gray, 1995) and the hydrological response of mountain rivers (Pomeroy et al., 2004). These factors play a significant role in water resource management relative to climate change scenarios worldwide (Barnett et al., 2005). This has been observed for Mediterranean mountains (GarcíaRuiz et al., 2011), not only because of the major effects of seasonal snowpack dynamics on stream flow dynamics (López-Moreno and García-Ruiz, 2004; Abbas et al., 2017) but also due to its effects on other geomorphological features such as permafrost and glaciers (Serrano et al., 2001; López-Moreno et al., 2016). Studies of snow on Iberian Mountains have utilized detailed information on snowpack distribution (Herrero et al., 2009; López-Moreno et al., 2008; Revuelto et al., 2016a; Pimentel et al., 2017). The present study sought to develop a simple method of generating daily small scale snow depth distribution maps in remote mountain areas, based on automatically generated snow variables and pre-existing observations of snow depth distribution at peak snow accumulation over several snow seasons.

Understanding snow-related processes requires detailed information on the spatiotemporal changes in various snowpack variables. Using snowpack models (Bartelt and Lehning, 2002; Vionnet et al., 2012) and currently available computational resources, snow researchers can simulate snowpack evolution in remote areas at any time having details on any snow variable. Despite the good results of snowpack models for many operational applications, forecasted values can deviate when snow dynamics are simulated on heterogeneous mountain terrain at medium to small scales (Revuelto et al., 2018). Thus, a fuller understanding of snowpack evolution in mountain areas requires both (i) continuous automatic observations and (ii) field observations to obtain detailed snapshots of snowpack variables. Automatic Weather Stations (AWS) placed in mountain areas may be equipped with sensors, usually ultrasonic or laser sensors, that measure snow depth, Snow Water Equivalent (SWE, snow pillows or snow scales) or snow surface temperature/albedo (infrared sensors/radiometers). These systems provide high temporal resolution of certain snowpack variables at particular locations $\left(\sim \mathrm{m}^{2}\right.$, usually named in-situ observations). However, few snow variables can be continuously observed over large areas by autonomous sensors. These include the snow covered area extent generated by time-lapse photography with specific routines (Corripio, 2004; Härer et al., 2013; Dizerens, 2016). Thus, fieldwork is required to obtain distributed information of particular snowpack variables at precise times. Information on snowpack distribution has been traditionally provided by manual measurements, with different sampling strategies at various spatial scales used to measure SWE and snow depth (Watson et al., 2006; Jost 
et al., 2007, 2009; López-Moreno et al., 2011, 2013). However, manual sampling is not feasible over large areas because of the time involved. Over the last decade, light detection and ranging (LiDAR) technologies, including both Terrestrial Laser Scanning (TLS) and Airborne Laser Scanning (ALS), have been recursively applied to measure snow depth distributions in different study areas, with these methods yielding encouraging results (Deems et al., 2013). The large database of snow depth distribution maps generated with LiDAR technology worldwide has been exploited to better understand snowpack dynamics (Mott et al., 2010; Schirmer et al., 2011; Revuelto et al., 2015; Schön et al., 2015). Nevertheless data acquisition and data processing are time consuming and require highly specialized work teams and expensive measurement devices. Recently developed methods currently applied to mountain areas, such as unmanned aerial vehicles (UAVs) and high spatial resolution stereo satellite images (De Michele et al., 2016; Marti et al., 2016), have overcome some TLS/ALS limitations, but also have important meteorological and technical limitations that prevent the determination of snowpack distribution on a regular basis. Thereby, there is a scientific need to formulate methods that allow the generation of snow depth distribution maps without remote sensing observations, by combining certain automatically acquired snowpack variables. The present study sought to develop a novel and simple method of generating daily snow depth maps from observations automatically obtained in mountain areas.

The methodology was designed and its results evaluated in the Izas Experimental Catchment (Central Spanish Pyrenees). This site is equipped with an AWS that can determine changes in snow depth over time on a precise location, as well as a time-lapse camera that can be used to assess snow cover extent on a daily basis. Moreover, a TLS database of snow depth at high spatial resolution is available for particular dates from 2011 to 2017 (Revuelto et al., 2017). This approach utilizes mean values of the TLS annual peak accumulation to calculate the ratio among snow depths pixels. These ratios were subsequently used to generate daily snow depth distribution maps, by combining snow depth from the AWS and the snow cover extent derived from time-lapse images.

\section{Study site and period}

The Izas Experimental Catchment is located in the Central Spanish Pyrenees $\left(42^{\circ} 44^{\prime} \mathrm{N}, 0^{\circ} 25^{\prime} \mathrm{W}\right)$, at the headwaters of the Gallego River. Its elevation ranges from 2000 to $2300 \mathrm{~m}$ above sea level, with a surface of approximately 55 ha. Snow covers most of the study area from November to May (López-Moreno et al., 2010), with snow patches in preferential snow accumulation areas generally lasting until July. The catchment is mainly covered with high mountain pastures and some rocky outcrops in steeper areas. It is predominantly east-facing, with some areas also facing north or south. The catchment has a mean slope of $16^{\circ}$ (López-Moreno et al., 2012), with flat, concave and convex areas (Fig. 1). The characteristics of the Izas Experimental Catchment make this site appropriate for studying snowpack dynamics in a subalpine mountain environment. The absence of trees, the small size of the study site, and the average gentle slope make possible in-depth analyses of small-scale snowpack interaction with topography and atmosphere. Since the selection and instrumentalization of this study 
site in the 1980s (Alvera et al., 1991), studies have analyzed various scientific questions, including sediment transport (Alvera and Garcia-Ruiz, 2000; Lana-Renault et al., 2011), mountain landscape properties related to vegetation and topographic characteristics (del Barrio et al., 1997), and several snow-related processes (Anderton et al., 2002, 2004; López-Moreno et al., 2010, 2013, 2014, 2014b).

The study site is equipped with an AWS, which measures air pressure [mbar], relative humidity [\%] and air temperature $\left[{ }^{\circ} \mathrm{C}\right]$; wind speed $[\mathrm{m} / \mathrm{s}]$ and direction $\left[{ }^{\circ}\right.$ from North]; solar radiation $\left[\mathrm{W} \mathrm{m}^{-2}\right.$ day](incident and reflected); soil temperature $\left[{ }^{\circ} \mathrm{C}\right]$, water discharge $\left[\mathrm{m}^{3} / \mathrm{s}\right]$; precipitation $[\mathrm{mm}]$; snow depth $[\mathrm{m}]$ and the temperature of the snow surface $\left[{ }^{\circ} \mathrm{C}\right]$. In addition, a digital camera takes three photographs per day (time-lapse photography) of the east facing area of the catchment. The images obtained cover approximately 30 ha of the study area. Since the winter of 2011-2012, the snow depth distribution has been measured 2 to 6 times per snow season with a TLS. Time-lapse photographs and AWS observations have also been available for the time period between 2011 and 2017. These six snow seasons were selected for testing the methodology defined in this work. This study period included snow seasons with above average (2012-13, 2013-14), below average (2011-12 and 201617) and average (2014-15 and 2015-16) snow accumulations (Revuelto et al., 2017).

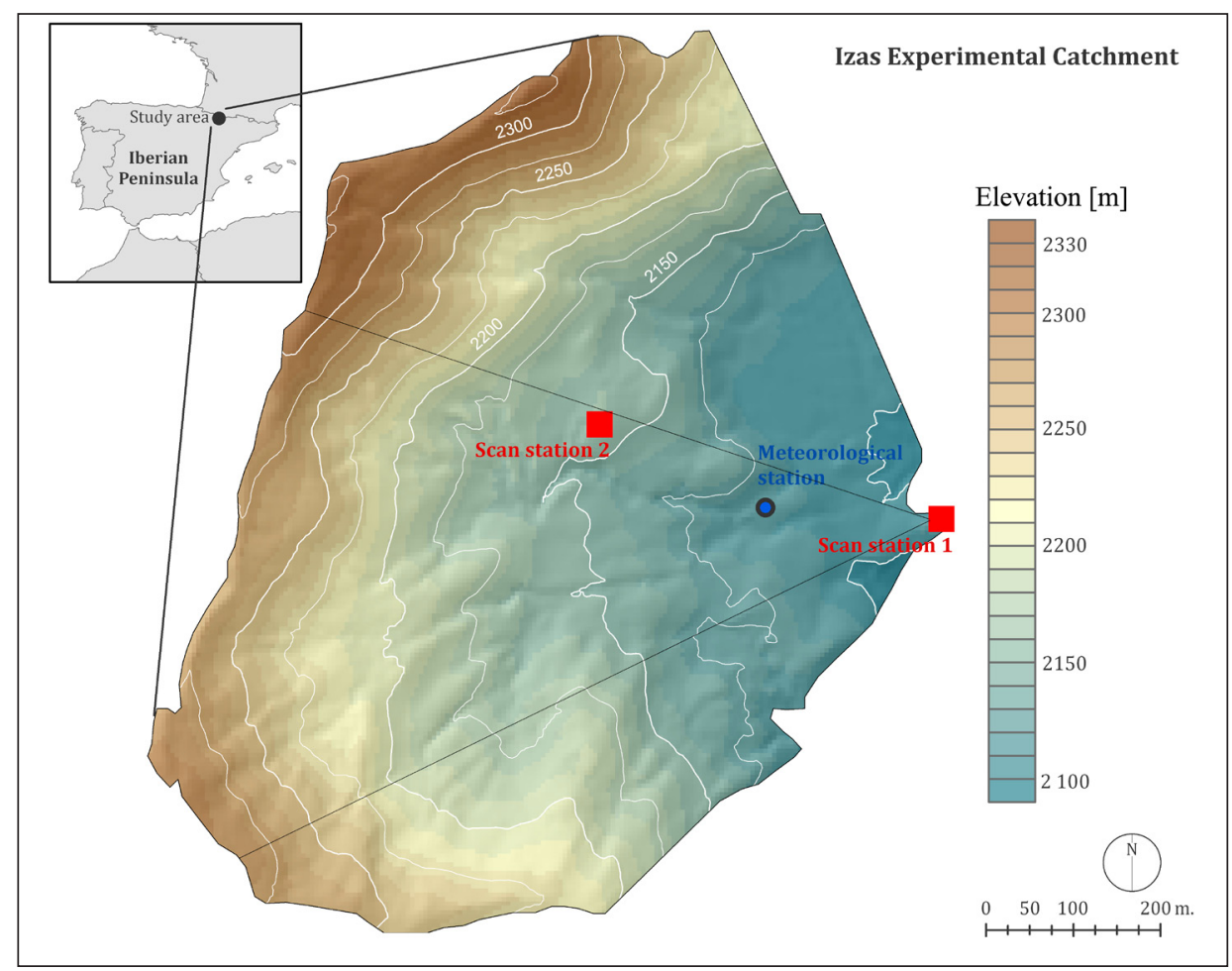

Figure 1. Location of the Izas Experimental Catchment. Red squares denote the location of the two scanning positions of the TLS. Continuous lines from Scan station 1 delimit the area covered by time lapse images. 


\section{Methods and database}

The methodology to generate daily snow depth distribution maps is mainly sustained on the strong topographic control of snowpack distributions observed in mountain areas. These areas show strong inter- and intra-annual consistency (Revuelto et al., 2014a; López-Moreno et al., 2017), indicating that the main snow distribution patterns are repeated from year to year (Sturm and Wagner, 2010). Once a repeat distribution pattern is confirmed in an area, the proposed method is designed to generate a daily database of snow depth distribution from automatically obtained observations of snow depth at a particular location and the distribution of snow presence or absence over the target area. The database available to test and define the methodology at the Izas Experimental Catchment was composed of 25 TLS snow depth distribution maps, georectified timelapse photographs of daily changes in snow covered area, and in-situ observations of changes in snow depth from the AWS.

\subsection{Terrestrial Laser Scanner snow depth maps}

Terrestrial laser scanners use LiDAR technology to measure the distance between the scanner and the target area, generating a three dimensional point cloud of the scanned surface. Once this information is georeferenced, based on the positions of fixed reflective targets within the study area, surfaces assessed at different times could be compared. Snow depth distribution is determined by subtracting the surface measured in the absence of snow during the summer from the snowy surface (Prokop, 2008). At distances up to $1000 \mathrm{~m}$ from the scanner, the mean absolute error in the snow depth maps has been reported to be $0.07 \mathrm{~m}$ (Revuelto et al., 2014b).

The TLS used for obtaining information on the snow depth distribution in the Izas Experimental Catchment is a long-range device (RIEGL LPM-321) with technical characteristics suitable for assessing snow distribution (Prokop, 2009). Details about the protocol used to acquire data in this study area and to generate the final snow depth distribution maps at a $1 \mathrm{~m}$ x $1 \mathrm{~m}$ spatial resolution have been reported in Revuelto et al. (2014b). Table 1 summarizes the average snow depths observed on various acquisition dates throughout the entire study period.

Table 1. Mean snow depth (SD) yearly TLS peak classification and snow covered areas on the 25 dates of scanning. This table also includes a comparison of seasonal classifications with the AWS climatic record.

\begin{tabular}{|c|c|c|c|c|c|}
\hline \multicolumn{2}{|c|}{ Date (scan number) } & Mean SD (m) & TLS Peak classif. & SCA (\%) & $\begin{array}{c}\text { Snow season } \\
\text { classification }\end{array}$ \\
\hline \multirow{4}{*}{$\begin{array}{c}\text { Snow season } \\
\text { 2011/12 }\end{array}$} & $22-02-12(1)$ & 0.46 & & 71 & \multirow{2}{*}{ Low snow accumulation } \\
\cline { 2 - 5 } & $02-04-12(2)$ & 0.17 & & 35 \\
\cline { 2 - 5 } & $17-04-12(3)$ & 0.56 & & \multicolumn{2}{|c}{100} \\
\cline { 2 - 5 } & $02-05-12(4)$ & 0.90 & Min. & 32 \\
\cline { 2 - 5 } & $14-05-12(5)$ & 0.21 & & 20 \\
\hline
\end{tabular}




\begin{tabular}{|c|c|c|c|c|c|}
\hline \multicolumn{2}{|c|}{ Date (scan number) } & Mean SD (m) & TLS Peak classif. & $\operatorname{SCA}(\%)$ & $\begin{array}{l}\text { Snow season } \\
\text { classification }\end{array}$ \\
\hline \multirow{6}{*}{$\begin{array}{l}\text { Snow season } \\
2012 / 13\end{array}$} & $17-02-13(7)$ & 2.91 & & 98 & \multirow{6}{*}{ High snow Accumulation } \\
\hline & 03-04-13(8) & 3.19 & Max. & 100 & \\
\hline & 25-04-13(9) & 2.42 & & 100 & \\
\hline & $06-06-13(10)$ & 1.98 & & 90 & \\
\hline & $12-06-13(11)$ & 1.69 & & 81 & \\
\hline & $20-06-13(12)$ & 0.76 & & 69 & \\
\hline \multirow{4}{*}{$\begin{array}{l}\text { Snow season } \\
2013 / 14\end{array}$} & $03-02-14(13)$ & 2.16 & & 98 & \multirow{4}{*}{ High snow Accumulation } \\
\hline & $22-02-14(14)$ & 2.56 & Max. & 100 & \\
\hline & $09-04-14(15)$ & 2.54 & & 93 & \\
\hline & $05-05-14(16)$ & 1.67 & & 77 & \\
\hline \multirow{4}{*}{$\begin{array}{l}\text { Snow season } \\
2014 / 15\end{array}$} & 06-Nov-14(17) & 0.22 & & 87 & \multirow{4}{*}{$\begin{array}{l}\text { Average snow accumu- } \\
\text { lation }\end{array}$} \\
\hline & $26-01-15(18)$ & 0.74 & & 93 & \\
\hline & $06-03-15(19)$ & 2.13 & Average & 100 & \\
\hline & $12-05-15(20)$ & 0.67 & & 58 & \\
\hline \multirow{3}{*}{$\begin{array}{l}\text { Snow season } \\
2015 / 16\end{array}$} & $04-02-16(21)$ & 0.82 & & 94 & \multirow{3}{*}{$\begin{array}{l}\text { Average snow accumu- } \\
\text { lation }\end{array}$} \\
\hline & $25-04-16(22)$ & 1.86 & Average & 100 & \\
\hline & $26-05-16(23)$ & 1.16 & & 44 & \\
\hline \multirow{2}{*}{$\begin{array}{l}\text { Snow season } \\
2016 / 17\end{array}$} & $20-01-17(24)$ & 1.26 & Min. & 100 & \multirow{2}{*}{ Low snow accumulation } \\
\hline & $08-05-17(25)$ & 0.77 & & 59 & \\
\hline
\end{tabular}

\subsection{Snow-covered area from time-lapse photography}

In 2011, a Campbell CC640 digital camera was installed in the study area. This camera automatically takes three photographs per day of the study area, with these photographs covering approximately $55 \%$ of the surface. Despite providing photographs every day, photographs on about $20 \%$ of the days had to be discarded because the presence of clouds and/or due to ice on the camera lens. Using previously described methodology (Corripio, 2004), the RGB information of the images was projected into a Digital Elevation Model (DEM) with $1 \mathrm{~m}$ spatial resolution. This method was based on an initial georectification of the images, which considers the characteristics of the camera lens and the correspondence between the camera pixels and their exact GPS position, and a recursive projection of all photographs. The procedure used to generate the database of the distribution of snow covered areas (snow presence/absence) in the Izas Experimental Catchment has been described previously (Revuelto et al., 2016b). The final product had the same geometry as the snow depth distribution obtained with the TLS. Both databases are available in UTM 30N (ETRS89 datum) with the same limits and the same spatial resolution (1 $\mathrm{m} \times 1 \mathrm{~m})$, enhancing the applicability of the methods defined in this study. Table 1 includes information on the Snow Covered Area (SCA) of TLS scanning dates derived from georectified time-lapse photographs. 


\subsection{Generation of daily snow depth distribution maps}

Several steps were required to generate daily databases of snow depth distribution:

1. In the first step, the ratios of average snow depth for each pixel to the maximum average snow depths at various yearly snow peak observation times were calculated. Average snow depth distributions were obtained from the selected scans (note that various combinations of annual TLS observations were tested). Subsequently, the ratio $(P(x, y))$ between the mean snow depth for each grid cell $\left(S D_{a v g}(x, y)\right)$ and the maximum mean snow depth value $\left(S D_{\max }\right)$ was calculated using the equation:

$$
P(x, y)=\frac{S D_{a v g}(x, y)}{\operatorname{Max}\left[S D_{a v g}(x, y)\right]}=\frac{S D_{a v g}(x, y)}{S D_{\max }}
$$

Thus, $P(x, y)$ is a ratio that falls in the interval $(0,1]$. Moreover, all yearly snow peaks in the study area were entirely covered with snow.

2. In the second step, the $P(x, y)$ ratios from step 1 for each time with valid timelapse photographs were rescaled to their original interval of $(0,1]$ for snow covered pixels, with snow free pixels assigned a value of 0 . That is, the snow cover distribution information (snow presence/absence) obtained with the digital camera was exploited to generate daily $P(x, y, t)$ ratios, all of which fell within the same interval, i.e., 0 for snow free pixels and $(0,1]$ for snow covered pixels.

3. Subsequently, the daily snow depth distributions were obtained using a direct proportionality rule among the quotidian $P(x, y, t)$ from step 2 and the snow depth observed by the AWS. This allowed calculations of snow depth for each pixel and each day:

$$
S D_{\text {model }}(x, y, t)=\frac{p(x, y, t)}{P_{o b s}} S D_{o b s}(t)
$$

where $S D_{\text {model }}(x, y, t)$ is the simulated snow depth at pixel $(x, y)$ on day $t, P(x, y)$ is the ratio for pixel $(x, y), P_{o b s}=P\left(x_{o b s}, y_{o b s}, t_{o b s}\right)$ is the ratio at the AWS location and $S D_{o b s}(t)$ is the daily snow depth at the AWS.

Calculations of the snow depth distribution for the entire period were based on two simple premises: $(i)$ when the study area is entirely covered, ratios remain constant and (ii) when the study area is partially snow covered, $P(x, y)$ ratio can be rescaled to the original interval $(0,1]$ for the snow covered area, and forced to zero for pixels not snow covered $\left(P_{S C A=0}(x, y)=0\right)$. A prerequisite for these premises is that TLS snow depth distribution maps at the time of maximum annual accumulation show an SCA of $100 \%$ in daily georectified images (Table 1). 


\subsection{Selection of peak accumulation years}

Different combinations of TLS snow depth maps at the times of peak annual accumulation were tested to assess the impact on the modeled results of including or not including years with different climatic characteristics, as illustrated by snow accumulation. After considering the peak TLS classifications summarized in Table1, the following combinations of TLS peak accumulation maps were tested:

i) All: Mean of all peak TLS (the six yearly peak dates)

ii) Max: Mean of maximum peak TLS (2013 and 2014 peak dates)

iii) Average: Mean of average peak TLS (2015 and 2016 peak dates)

iv) Min: Mean of minimum peak TLS (2012 and 2017 peak dates)

For each of these four TLS peak combinations, a different distribution of $P$ ratios of the base to the mean values obtained from eq. (1) was generated.

\subsection{Synthetic in-situ snow depth}

The methodology presented in this study has an important limitation. In the absence of snow at an AWS location, it was impossible to generate the snow depth distribution. This was applicable to seven of the 25 TLS snow depth maps available, mostly at the end of the snow season. Despite the ability of the methods presented in this study to generate a daily database of snow depth distributions, the only alternative is to evaluate the results with snow distribution obtained from TLS observations. Moreover, as the average snow depth distribution at peak snow accumulation was calculated based on two to six TLS observations, the number of independent observations available to evaluate the performance of the methodology was drastically reduced. To overcome these limitations, and to be able to test simulated results for all TLS observation dates, a procedure was established to generate synthetic in-situ snow depth observations for dates on which AWS showed no snow.

The synthetic in-situ snow depth was defined as the average of all TLS observed snow depths belonging to a particular $P(x, y)$ ratio interval. This average value was considered an in-situ snow depth observation to generate snow depth distributions from equation. Four different $P(x, y)$ ratio intervals were tested: $P(x, y)=0.15 \pm 0.02$, $P(x, y)=0.30 \pm 0.02, P(x, y)=0.40 \pm 0.02$ and $P(x, y)=0.50 \pm 0.02$ (hereafter called O_15, O_30, O_40 and O_50, respectively). Because AWS ratios $\left(P_{o b s}\right)$ ranged from $0.12-0.17$ for the different TLS peak combinations presented in Section 3.4, the results obtained with the O_15 synthetic observations can be compared with those obtained from true in-situ observations of snow depth. This method also allows testing of the impact of potentially placing the AWS at locations with particular characteristics of snow depth accumulation. 


\subsection{Simulated versus observed snow depths}

During the entire study period, four simulations with almost daily outputs were obtained for the four TLS peak combinations described in Section 3.4 (we must remember that due to environmental conditions limiting visibility, time-lapse images were not available for about $20 \%$ of the days). The four simulations were calculated from equation (2), based on changes in snow depth over time observed at the AWS $\left(S D_{o b s}(t)\right)$. Additionally, for each of the four simulations, the snow depth distributions on the TLS scanning dates were calculated using the four synthetic in-situ snow depth observations. A total of 20 combinations were generated for four different $P$ ratios and five different in-situ snow observations (including both true and synthetic observations) for almost all TLS dates.

To assess the capability of the method described above the snow depth distribution maps simulated are evaluated against the snow depth observed with the TLS. The evaluation is based on the temporal changes in the coefficient of determination (R2) and the standardized Root Mean Squared Error (RMSE). To assess the overall performance of each of the 20 possible evaluations, the mean values of $\mathrm{R}^{2}$ and RMSE were computed for TLS dates on which snow was present on the AWS (i.e., dates on which it was possible to assess snow depth distribution for every evaluation).

\section{Results}

Simulations using the $P$ ratio obtained from the average of the six yearly TLS peaks (All selection) showed better performance than the other $P$ ratios in reproducing observed snow depth distributions (Table 2). This superior result was obtained for both AWS and synthetic snow depth observations. Moreover, optimal improvement was obtained using the O_30 synthetic observation. O_50 synthetic observations in Table 2 were not further analyzed, because O_30 and O_40 showed better simulation results. Although the above results showed that the model obtained from the six yearly TLS peaks was better at reproducing snow depth distribution, it was necessary conduct additional analyses of the temporal changes in R2 and RMSE metrics.

Table 2. Average RMSE and R2 for comparisons of observed and simulated snow depth distributions. Columns present the values obtained for the four $P$ ratios derived from the combinations of TLS yearly peak accumulations for the different observations.

\begin{tabular}{|c|c|c|c|c|c|c|c|c|}
\hline \multirow{2}{*}{$\begin{array}{c}\text { Pratio } \\
\text { Obs. }\end{array}$} & \multicolumn{2}{|c|}{ All } & \multicolumn{2}{|c|}{ Max } & \multicolumn{2}{|c|}{ Avg. } & \multicolumn{2}{|c|}{ Min } \\
\hline & RMSE (m) & $\mathbf{R} 2$ & RMSE (m) & $\mathbf{R} 2$ & RMSE (m) & $\mathbf{R 2}$ & RMSE (m) & $\mathbf{R} 2$ \\
\hline AWS obs & 0.333 & 0.626 & 0.356 & 0.592 & 0.360 & 0.585 & 0.415 & 0.398 \\
\hline O_15 & 0.377 & 0.582 & 0.414 & 0.536 & 0.381 & 0.532 & 0.378 & 0.456 \\
\hline O_30 & 0.307 & 0.707 & 0.328 & 0.669 & 0.307 & 0.688 & 0.355 & 0.576 \\
\hline O_40 & 0.348 & 0.695 & 0.356 & 0.666 & 0.331 & 0.686 & 0.381 & 0.570 \\
\hline O_50 & 0.414 & 0.673 & 0.414 & 0.628 & 0.355 & 0.678 & 0.561 & 0.390 \\
\hline
\end{tabular}


Figures 2 and 3 depict encouraging results for TLS scanning dates with high snow accumulations. In contrast, dates with lower snow depths, generally at the end of the snow season, showed poorer results. For example, for the snow season with the lowest snow accumulation during the study period (2011-12), the calculations failed to reproduce the observed snow depth distributions on almost all dates. Only the fourth scanning date (02/05/2012, peak yearly observation) showed an R2 value $>0.8$ with the $P$ ratio derived from the average minimum TLS peaks. A similar result was observed during the season with the second lowest snow accumulation (2016-17).

The snow depth distributions calculated for high (2012-13 and 2013-14) and average (2014-15 and 2015-16) snow seasons showed results similar to simulations determined using $P$ ratios calculated from "All", "Max" and "Average" combinations of TLS yearly peaks. However, these three combinations also failed to reproduce the snow depth

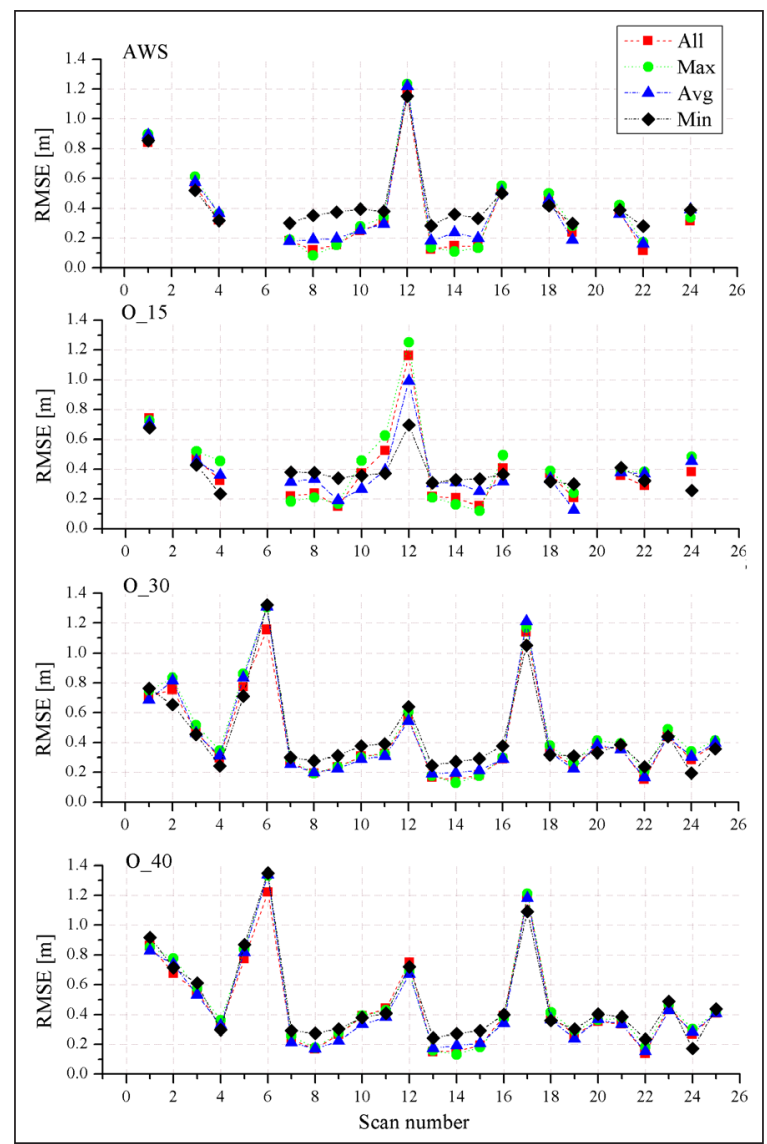

Figure 2. Normalized RMSE calculated by comparing observed and simulated snow depth distributions maps on the 25 scanning dates. The upper panels show results obtained with AWS snow depth observations and the lower panels show results obtained with $O \_15, O \_30$ and $O \_40$ synthetic observations. Each panel includes results from the different TLS peak combinations.

Vertical dashed lines depict the transition between snow seasons. 


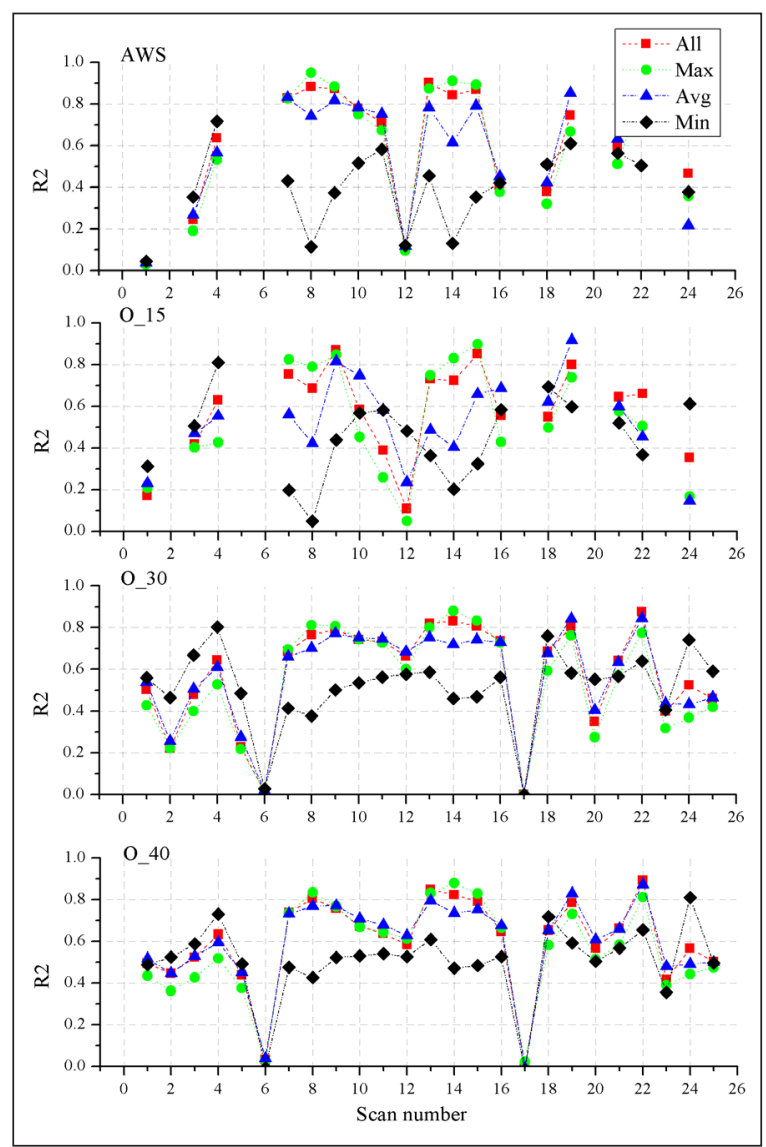

Figure 3. R2 calculated by comparing observed and simulated snow depth distributions maps on the 25 scanning dates. The upper panels show results obtained with AWS snow depth observations and the lower panels show results obtained with $O \_15, O \_30$ and $O \_40$ synthetic observations. Each panel includes results from the different $T L \bar{S}$ peak combinations. Vertical dashed lines depict the transition between snow seasons.

distributions during the earliest seasonal TLS observations (scan number 17, 06/11/ 2014), when average snow depth was low (0.22 m, Table 1$)$, but a high percentage $(87 \%)$ of the study area surface was covered with snow. During the two snow seasons with high snow accumulation, the TLS yearly peak combination that showed the best match with observed values was the "Max" combination. In contrast, during the average snow season, the best performance was obtained with either the "Average" or "All" TLS yearly peak combination. However, the differences among "All", "Average" and "Max" TLS peak combinations during seasons of average and high snow accumulation were minor.

Synthetic observations allowed generating snow depth distribution for TLS scanning dates to be generated without the presence of snow on the AWS. Thus, O_30 and O_40 synthetic observation graphs (Figs. 2 and 3) showed simulation performances 


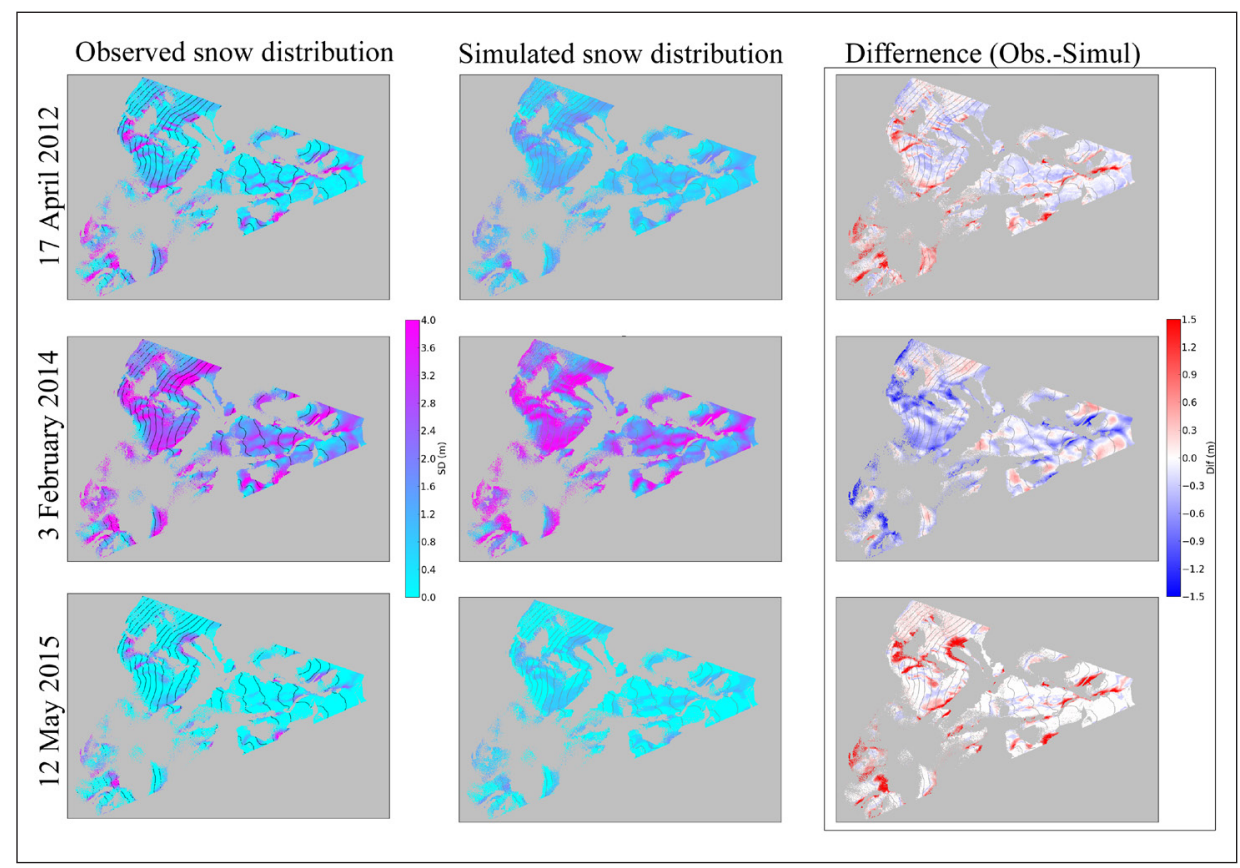

Figure 4. Observed (left panel) and simulated (central panel) snow depth distributions on three particular dates. The simulated snow depth maps were obtained with the O_30 synthetic observation and the Pratios obtained all TLS peak scans. Maps in the right panel represent the differences between the observed and simulated maps.

that would not have been possible otherwise. Additionally, the results of simulated snow depth distributions with O_15, O_30 and O_40 were similar to those obtained with the AWS observations on dates with snow presence at the AWS location.

Figure 4 shows the spatial distribution of the differences between observed and simulated (observed-predicted) snow depths on three particular dates. This figure also shows the observed and simulated snow depth distributions. The predicted snow depth distribution was obtained with the O_30 synthetic observation and with the $P$ ratio obtained from the combination of all TLS peak scans; this simulation showed better average results compared with to the other simulations (Table 2). Dates included in this figure were selected because they showed most of the study area snow covered and because they belonged to snow seasons that differed in snow climatic characteristics (i.e., low, high and average snow seasons).

On 14/04/2012, the Izas Experimental Catchment was almost entirely covered with snow, with an average snow depth of $0.56 \mathrm{~m}$. This scan was obtained before the seasonal snow peak and thus is considered a scan during the period of accumulation. Differences between observed and simulated values indicated that the simulations underestimated areas of high snow accumulation, while overestimating areas of lower snow depths. Similar 
behavior was observed on 12/05/2015, in which the snowpack was dominated by melting dynamics, as this scan was obtained after the seasonal snow peak, with an SCA of 58\% and an average snow depth of $0.67 \mathrm{~m}$ ). The snow differences map showed that areas of high snow accumulation were underestimated. The differences observed on 02/02/2014, a scan obtained before the annual snow peak (i.e., during the accumulation period) with a marked snow accumulation (SCA of $93 \%$ and average snow depth of $2.16 \mathrm{~m}$ ), showed that the simulated snow depth distribution was overestimated in areas of high snow accumulation. Similar results were observed on scanning dates with equivalent characteristics (high and low snow accumulation during accumulation and melting periods, respectively). These findings show that, despite the ability of the methodology to reproduce snow depth distribution, deviations occur in areas of high and low snow accumulation.

\section{Discussion}

The methodology described in this work relies on the control of snowpack distribution by topography (Anderton et al., 2004; Erickson et al., 2005; Mott et al., 2013). Based on the inter-annual consistency of snow topographic control (Sturm and Wagner, 2010; Revuelto et al., 2014a), we developed a simple simulation procedure enabling the generation of small scale snow depth distribution maps from observations automatically obtained in remote mountain areas. This method requires knowledge of snow depth distribution on particular dates during different snow seasons. The snow depth distribution within the study area on any date can be derived from information on snow cover disposition obtained from georectified time-lapse photographs, in-situ observations of changes in snow depth and $P(x, y)$ ratios derived from TLS observations at peak annual snow accumulation. Although the simulation procedure is quite simple, it is based on two important premises: $(i)$ when the study area is entirely covered, ratios remain constant and (ii) when the study area is partially snow covered, $P(x, y)$ ratio can be rescaled to the original interval $(0,1]$ for the snow covered area, and forced to zero for pixels not snow covered $\left(P_{S C A=0}(x, y)=0\right)$.

One major limitation of the method described here is that it requires that snow be present at the location of the AWS when some areas of the catchment are snow covered. Thus, a quotidian in-situ observation of snow depth within the study area is needed to generate daily snow depth distributions. This approach has important constraints if snow is absent for long periods of time from the location of the in-situ snow depth observations. This was the case for seven of the 25 evaluation scanning dates during the study period. In light of this important limitation for testing simulation results, a method generating synthetic snow depth observations was introduced. Synthetic observations were defined as the average snow depths observed on grid cells belonging to an interval of $P$ ratios on TLS acquisition dates. These synthetic observations enabled the generation of snow depth distributions for dates that otherwise would not have been possible. Moreover, simulated values obtained with synthetic observations showed similar performances with values obtained from snow depth observations at the AWS. Taken together, these findings emphasize the importance of selecting an appropriate location for the AWS. If in-situ snow depth at the Izas Experimental Catchment had been measured in an area with other topographic characteristics (location 
favoring snow accumulation), reconstruction for a longer period would have been possible. Moreover choosing one or several locations for in-situ snow depth observations opens new possibilities for the methodology presented in this study. For example, different weights may be assigned depending on the time of the snow season or the snow covered area of the catchment to different in-situ snow depth observations. This opens new insights into the methodology because designing an experimental site with in-situ snow depth observations at particular locations based on preexisting knowledge of topographic control may enhance the ability to determine snow distribution within a study area.

Four different combinations of TLS seasonal snow peak observations were tested to obtain $P(x, y)$ ratios (designated "All", "Max", "Average" and "Min"). On most of the TLS scanning dates, results were similar for the "All", "Max", and "Average" combinations, with only minor differences in R2 and RMSE values. The "Min" ratios showed the poorest performance during high and average snow seasons and were not improved when compared with the other ratios during seasons of low snow accumulation (201112 and 2016-17). These findings indicate that the topographic control of snow depth distribution is reduced during years of low snow accumulation and is not transferable to years with average or high snow accumulation. Although results on some particular dates were poorer for the "All" than for the "Average" and "Max" combinations, $P$ ratios calculated using all TLS yearly snow peaks showed a superior average performance. Thus, average snow depth distributions generated by all TLS peak snow observations have the highest transferability among snow seasons.

On particular dates and during snow seasons with high and low snow accumulation, respectively the "Max" and "Min" TLS peak combinations yielded lower RMSE and higher R2 values. These findings indicate that snowpack distributions during years of high and low snow accumulation have particular characteristics that allow the establishment of different spatial patterns that are well reproduced on dates with similar snowpack accumulations. In contrast, these spatial patterns are not well reproduced when $P$ ratios are calculated from TLS yearly peak combinations with different snow conditions. Nevertheless, the average of yearly TLS snow peaks enabled the reproduction of small scale snow distributions for snow seasons with marked differences in snow accumulation, supporting the applicability of the simple methodology developed in the present work

Regardless of the capability of the proposed methodology to determine snow depth distribution from in-situ snow depth observations and georectified time-lapse photography for snowpacks with non-negligible depth and/or extent, the methods introduced completely failed to reproduce the snow depth distribution for dates with very low snow accumulation. This was mainly observed following scans early in the snow season (i.e. 06/11/2014) and late in the snow season after long periods of melting (i.e. 24/05/2012). At these times, the simulation approach is unable to generate the snowpack distribution observed. Moreover the methodology is unable to reproduce areas of high snow accumulation, underestimating snow accumulation during peak snow periods and overestimating snow depth during melting periods.

The results presented here are encouraging when compared with other simulation approaches (detailed snowpack models) with higher computational costs, methods that 
must be combined with TLS observations to obtain similar or superior performance (Revuelto et al., 2016a) than the methodology presented here. Nevertheless, the simulation procedure presented here is applicable only to simulating small-scale snowpack dynamics (from $1 \mathrm{~m}$ to $\sim 500 \mathrm{~m}$ ), in study areas with a pre-existent database of snow distribution dynamics. In contrast, detailed snowpack models (Vionnet et al., 2012) have a broader applicability over large areas and only require meteorological forecasting. The application to heterogeneous mountain areas of numerical meteorological models may result in large deviations, especially when considering simulations with high spatial resolution (Vionnet et al., 2016), which could introduce large deviations in numerical snowpack simulation (Raleigh et al., 2015). One potential future line of research is to combine the methods described here with detailed snowpack models that do not take into account the small-scale topographic control of snow depth distribution. In this regard, ensemble data assimilation techniques as particle filter and kalman filter have produced encouraging results simulating the snow evolution (Slater and Clark, 2006; Charrois et al., 2016). Similarly, novel approaches are accurately reproducing snowpack dynamics incorporating point snow observations in fully distributed snow models (Winstral et al., 2019). Linking these techniques with the approach described here, may overcome other limitations still present when simulating snow dynamics in heterogeneous mountain areas, as nowadays is topographic control on snow distribution (Revuelto et al., 2018).

The methodology we have introduced can be applied to any study area for which equivalent daily information is available, as long as the snow depth distribution around peak snow accumulation times is known for two snow seasons, along with average snow accumulation climatic characteristics. This method has great potential in remote mountain areas, in which snow distribution has been or could be acquired with UAVs and high spatial resolution satellite sensors (De Michele et al., 2016; Marti et al., 2016), along with AWS daily snow depth data, as satellite imagery can provide almost daily observations of snow presence or absence (Dumont and Gascoin, 2016). The systematic application of methods described here to remote mountain areas opens new insight on automatic monitoring systems of the snowpack not only for research objectives but also for protecting the society and infrastructures from mountain hazards as snow avalanches or floods. Thus future work is expected to implement and test methods described here in extended areas of the Pyrenees using UAV and satellites observations.

\section{Conclusions}

The present study was driven by the need to provide simple tools to the snow science community and researchers from other disciplines (e.g. plant ecologists, geomorphologists) that can be used to generate daily snow depth distribution maps from automatically acquired assessments of snow. Moreover, future work will amplify the monitoring area, combining TLS observations with UAV and satellite image acquisitions. The methodology developed in this study was tested in the Izas Experimental Catchment over six snow seasons. The simulation combines daily information on in-situ snow depth observations, snow covered extents from georectified time-lapse photography and snow depth distributions observed with a TLS on yearly snow peak accumulation. 
Four different combinations of yearly peaks to generate the snow ratio among snow map grid cells were tested. Simulation results have been tested against 25 TLS observations available at the study site. The method is supported by the strong topographic control that terrain exerts on snowpack distribution in mountainous areas. The major findings of this research can be summarized as follows:

Combining time-lapse photographs with in-situ snow depth observations and a preexistent database of snow depth maps, following the methodology proposed here; allows simulating snow depth distribution on almost a daily basis in remote mountain areas.

1. Superior results are obtained when using information from a long lasting database of TLS observations (averaging all annual TLS peak observations). However, almost same results are obtained when data from average snow accumulation seasons are used in the algorithm.

2. Determining the snow depth distribution at peak accumulation times over two snow seasons with average snow climatic characteristics may be sufficient to generate daily snow depth maps with the methodology described here.

This method may be transferable to other study areas with similar experimental setups and for which similar snowpack observations are available (daily snow distribution, AWS observations and 2-3 peak snow depth distribution maps). Use of this method can avoid the recursive application of time consuming techniques using expensive acquisition devices to generate detailed snow depth distribution maps in remote mountain areas that are difficult to access.

\section{Acknowledgments}

J. Revuelto is supported by a Post-doctoral Fellowship from the AXA research fund (le Post-Doctorant Jesús Revuelto est bénéficiaire d'une bourse postdoctorale du Fonds AXA pour la Recherchem Ref: CNRM 3.2.01/17). Esteban Alonso-González is supported by the Spanish Ministry of Economy and Competitiveness (BES- 2015-071466)

\section{References}

Abbas, F., Gascoin, S., Faour, G., López-Moreno, J.I., Drapeau, L., Michel Le Page, Escadafal, R. 2017. Snow hydrology in Mediterranean mountain regions: A review. Journal of Hydrology 551, 374-396. https://doi.org/10.1016/j.jhydrol.2017.05.063.

Alvera, B., Garcia-Ruiz, J.M. 2000. Variability of Sediment Yield from a High Mountain Catchment, Central Spanish Pyrenees. Arctic, Antarctic, and Alpine Resesearch 32, 478-484. https://doi.org/10.1080/15230430.2000.12003392.

Alvera, B., Del Barrio, G., Diez, J.C. 1991. The Izas Experimental Catchment, Central Pyrenees. Instituto Pirenaico de Ecología.

Anderton, S.P., White, S.M., Alvera, B. 2002. Micro-scale spatial variability and the timing of snow melt runoff in a high mountain catchment. Journal of Hydrology 268, 158-176.

Anderton, S.P., White, S.M., Alvera, B. 2004. Evaluation of spatial variability in snow water equivalent for a high mountain catchment. Hydrological Processes 18, 435-453. https://doi. org/10.1016/S0022-1694(02)00179-8. 
Barnett, T.P., Adam, J.C., Lettenmaier, D.P. 2005. Potential impacts of a warming climate on water availability in snow-dominated regions. Nature 438, 303-309. https://doi.org/10.1038/ nature04141.

del Barrio, G., Alvera, B., Puigdefabregas, J., Diez, C. 1997. Response of high mountain landscape to topographic variables: Central Pyrenees. Landscape Ecology 12, 95-115. https://doi. org/10.1007/BF022698210.

Bartelt, P., Lehning, M. 2002. A physical SNOWPACK model for the Swiss avalanche warning: Part I: numerical model. Cold Regions Science and Technology 35, 123-145. https://doi. org/10.1016/S0165-232X(02)00074-5.

Charrois, L., Cosme, E., Dumont, M., Lafaysse, M., Morin, S., Libois, Q., Picard, G. 2016. On the assimilation of optical reflectances and snow depth observations into a detailed snowpack model. The Cryosphere 10, 1021-1038. https://doi.org/10.5194/tc-10-1021-2016.

Corripio, J.G. (2004). Snow surface albedo estimation using terrestrial photography. International Journal of Remote Sensing 25, 5705-5729. https://doi.org/10.1080/01431160410001709002.

De Michele, C.D., Avanzi, F., Passoni, D., Barzaghi, R., Pinto, L., Dosso, P., Ghezzi,A., Gianatti, R., Vedova, G.D. 2016. Using a fixed-wing UAS to map snow depth distribution: an evaluation at peak accumulation. The Cryosphere 10, 511-522. https://doi.org/10.5194/tc-10-511-2016.

Deems, J.S., Painter, T.H., Finnegan, D.C. 2013. Lidar measurement of snow depth: a review. Journal of Glaciology 59, 467-479. https://doi.org/10.3189/2013JoG12J154.

Dizerens, C. 2016. Georectification and snow classification of webcam images: potential for complementing satellite-derived snow maps over Switzerland. Master Thesis, University of Bern, 75 pp.

Dumont, M., Gascoin, S. 2016. 4 - Optical remote sensing of snow cover. In: N. Baghdadi, M. Zribi (Eds), Land surface remote sensing in continental hydrology. Elsevier, pp. 115-137. https://doi.org/10.1016/B978-1-78548-8.50004-8.

Erickson, T.A., Williams, M.W., Winstral, A. 2005. Persistence of topographic controls on the spatial distribution of snow in rugged mountain terrain, Colorado, United States. Water Resources Reearch 41 (4), 1-17. https://doi.org/10.1029/2003WR002973.

García-Ruiz, J.M., López-Moreno, J.I., Vicente-Serrano, S.M., Lasanta-Martínez, T., Beguería, S. 2011. Mediterranean water resources in a global change scenario. Earth-Science Reviews 105, 121-139. https://doi.org/10.1016/j.earscirev.2011.01.006.

Härer, S., Bernhardt, M., Corripio, J.G. Schulz, K. 2013. PRACTISE - Photo Rectification And ClassificaTIon SoftwarE (V.1.0). Geoscientific Model Development 6, 837-848. https://doi. org/10.5194/gmd-6-837-2013.

Herrero, J., Polo, M.J., Moñino, A., Losada, M.A. 2009. An energy balance snowmelt model in a Mediterranean site. Journal of Hydrology 371, 98-107. https://doi.org/10.1016/j. jhydrol.2009.03.021.

Jost, G., Weiler, M., Gluns, D.R., Alila, Y. 2007. The influence of forest and topography on snow accumulation and melt at the watershed-scale. Journal of Hydrology 347, 101-115. https:// doi.org/10.1016/j.jhydrol.2007.09.006.

Jost, G., Dan Moore, R., Weiler, M., Gluns, D.R., Alila, Y. 2009. Use of distributed snow measurements to test and improve a snowmelt model for predicting the effect of forest clearcutting. Journal of Hydrology 376, 94-106. https://doi.org/10.1016/j.jhydrol.2009.07.017.

Lana-Renault, N., Alvera, B., García-Ruiz, J.M. 2011. Runoff and Sediment Transport during the Snowmelt Period in a Mediterranean High-Mountain Catchment. Arctic, Antarctic and Alpine Research 43, 213-222. https://doi.org/10.1657/1938-4246-43.2.213.

López-Moreno, J.I., García-Ruiz, J.M. (2004). Influence of snow accumulation and snowmelt on streamflow in the central Spanish Pyrenees. Hydrological Sciences Journal 49, 787-802. https://doi.org/10.1623/hysj.49.5.787.55135. 
López-Moreno, J.I., Beniston, M., García-Ruiz, J.M. 2008. Environmental change and water management in the Pyrenees: Facts and future perspectives for Mediterranean mountains. Global and Planetary Change 61, 300-312. https://doi.org/10.1016/j.gloplacha.2007.10.004.

López-Moreno, J.I., Latron, J., Lehmann, A. 2010. Effects of sample and grid size on the accuracy and stability of regression-based snow interpolation methods. Hydrological Processes 24, 1914-1928. https://doi.org/10.1002/hyp.7564.

López-Moreno, J.I., Fassnacht, S.R., Beguería, S., Latron, J.B.P. 2011. Variability of snow depth at the plot scale: implications for mean depth estimation and sampling strategies. The Cryosphere 5, 617-629. https://doi.org/10.5194/tc-5-617-2011.

López-Moreno, J.I., Pomeroy, J.W., Revuelto, J., Vicente-Serrano, S.M. 2012. Response of snow processes to climate change: spatial variability in a small basin in the Spanish Pyrenees. Hydrological Processes 27, 2637-2650. https://doi.org/10.1002/hyp.9408.

López-Moreno, J.I., Fassnacht, S.R., Heath, J.T., Musselman, K.N., Revuelto, J., Latron, J., Morán-Tejeda, E., Jonas, T. 2013. Small scale spatial variability of snow density and depth over complex alpine terrain: Implications for estimating snow water equivalent. Adances in Water Resources 55, 40-52. https://doi.org/10.1016/j.advwatres.2012.08.010.

López-Moreno, J.I., Revuelto, J., Fassnacht, S.R., Azorín-Molina, C., Vicente-Serrano, S.M., Morán-Tejeda, E., Sexstone, G.A. 2014. Snowpack variability across various spatio-temporal resolutions. Hydrological Processes 29 (6), 1213-1224. https://doi.org(10.1002/hyp.10245.

López-Moreno, J.I., Revuelto, J., Rico, I., Chueca-Cía, J., Julián, A., Serreta, A., Serrano, E., Vicente-Serrano, S.M., Azorin-Molina, C., Alonso-González, E., García-Ruiz, J.M. 2016. Thinning of the Monte Perdido Glacier in the Spanish Pyrenees since 1981. The Cryosphere 10, 681-694. https://doi.org/10.5194/tc-10-681-2016.

López-Moreno, J.I., Revuelto, J., Alonso-González, E., Sanmiguel-Vallelado, A., Fassnacht, S.R., Deems, J., Morán-Tejeda, E. 2017. Using very long-range terrestrial laser scanner to analyze the temporal consistency of the snowpack distribution in a high mountain environment. Journal of Mountain Science 14, 823-842. https://doi.org/10.1007/s11629-016-4086-0.

Marti, R., Gascoin, S., Berthier, E., Pinel, M. de, Houet, T., Laffly, D. 2016. Mapping snow depth in open alpine terrain from stereo satellite imagery. The Cryosphere 10, 1361-1380. https:// doi.org/10.5194/tc-10-1361-2016.

Mott, R., Schirmer, M., Bavay, M., Grünewald, T., Lehning, M. 2010. Understanding snowtransport processes shaping the mountain snow-cover. The Cryosphere 4, 545-559. https:// doi.org/10.5194/tc-4-545-2010.

Mott, R., Gromke, C., Grünewald, T., Lehning, M. 2013. Relative importance of advective heat transport and boundary layer decoupling in the melt dynamics of a patchy snow cover. Advances in Water Resources 55, 88-97. https://doi.org/10.1016/j.advwatres.2012.03.001.

Pimentel, R., Herrero, J., Polo, M. 2017. Quantifying Snow Cover Distribution in Semiarid Regions Combining Satellite and Terrestrial Imagery. Remote Sensing 9, 995. https://doi. org/10.3390/rs9100995.

Pomeroy, J.W., Gray, D.M. 1995. Snowcover accumulation, relocation, and management. National Hydrology Research Institute Science Report No 7, Environment Canada: Saskatoon, SA, $134 \mathrm{pp}$.

Pomeroy, J., Essery, R., Toth, B. 2004. Implications of spatial distributions of snow mass and melt rate for snow-cover depletion: observations in a subarctic mountain catchment. Annals of Glaciology 38, 195-201. https://doi.org/10.3189/172756404781814744.

Prokop, A. 2008. Assessing the applicability of terrestrial laser scanning for spatial snow depth measurements. Cold Regions Science and Technology 54, 155-163. https://doi.org/10.1016/j. coldregions.2008.07.002. 
Prokop, A. 2009. Terrestrial laser scanning for snow depth observations: An update on technical developments and applications. In: Proceedings of the International Snow Science Workshop, Davos, pp. 192-196.

Raleigh, M.S., Lundquist, J.D., Clark, M.P. 2015. Exploring the impact of forcing error characteristics on physically based snow simulations within a global sensitivity analysis framework. Hydrology and Earth System Sciences 19, 3153-3179. https://doi.org/10.5194/ hess-19-3153-2015.

Revuelto, J., López-Moreno, J.I., Azorin-Molina, C., Vicente-Serrano, S.M. 2014a. Topographic control of snowpack distribution in a small catchment in the central Spanish Pyrenees: Intraand inter-annual persistence. The Cryosphere 8, 1989-2006. https://doi.org/10.5194/tc-81989-2014.

Revuelto, J., López-Moreno, J.I., Azorin-Molina, C., Zabalza, J., Arguedas, G., Vicente-Serrano, S.M. 2014b. Mapping the annual evolution of snow depth in a small catchment in the Pyrenees using the long-range terrestrial laser scanning. Journal of Maps 10, 1-15. https:// doi.org/10.1080/17445647.2013.869268.

Revuelto, J., López-Moreno, J.I., Azorin-Molina, C., Vicente-Serrano, S.M. 2015. Canopy influence on snow depth distribution in a pine stand determined from terrestrial laser data. Water Resources Research 51,3476-3489. https://doi.org/10.1002/2014WR016496.

Revuelto, J., Vionnet, V., López-Moreno, J.I., Lafaysse, M., Morin, S. 2016a. Combining snowpack modeling and terrestrial laser scanner observations improves the simulation of small scale snow dynamics. Journal of Hydrology 533, 291-307. https://doi.org/10.1016/j. jhydrol.2015.12.015.

Revuelto, J., Jonas, T., López $\square$ Moreno, J.I. 2016b. Backward snow depth reconstruction at high spatial resolution based on time-lapse photography. Hydrological Processes 30, 2976-2990. https://doi.org/10.1002/hyp.10.823.

Revuelto, J., Azorin-Molina, C., Alonso-González, E., Sanmiguel-Vallelado, A., Navarro-Serrano, F., Rico, I., López-Moreno, J.I. 2017. Meteorological and snow distribution data in the Izas Experimental Catchment (Spanish Pyrenees) from 2011 to 2017. Earth System Science Data 9, 993-1005. https://doi.org/10.5194/essd-9-993-2017.

Revuelto, J., Lecourt, G., Lafaysse, M., Zin, I., Charrois, L., Vionnet, V., Dumont, M., Rabatel, A., Six, D., Condom, T., Morin, S., Viani, A., Sirguey, P. 2018. Multi-criteria evaluation of snowpack simulations in complex alpine terrain using satellite and in situ observations. Remote Sensing 10 (8), 1171. https://doi.org/10.3390/re10081171.

Schirmer, M., Wirz, V., Clifton, A., Lehning, M. 2011. Persistence in intra-annual snow depth distribution: 1.Measurements and topographic control. Water Resources Research 47, W09516. https://doi.org/10.1029/2010WR009426.

Schön, P., Prokop, A., Vionnet, V., Guyomarc'h, G., Naaim-Bouvet, F., Heiser, M. 2015. Improving a terrain-based parameter for the assessment of snow depths with TLS data in the Col du Lac Blanc area. Cold Regions Science and Technology 114, 15-26. https://doi.org/10.1016/j. coldregions.2015.02.005.

Serrano, E., Agudo, C., Delaloyé, R., González-Trueba, J.J. 2001. Permafrost distribution in the Posets massif, Central Pyrenees. Nordisk Geografisk Tidsskrift / Nordic Journal of Geography 55, 245-252. https://doi.org/10.1080/00291950152746603.

Slater, A.G., Clark, M.P. 2006. Snow Data Assimilation via an Ensemble Kalman Filter. Journal of Hydrometeorology 7, 478-493. https://doi.org/10.1175/JHM505.1.

Sturm, M., Wagner, A.M. 2010. Using repeated patterns in snow distribution modeling: An Arctic example. Water Resources Resarch 46 (12). https://doi.org/10.1029/2010WR009434. 
Vionnet, V., Brun, E., Morin, S., Boone, A., Faroux, S., Le Moigne, P., Martin, E., Willemet, J.M. 2012. The detailed snowpack scheme Crocus and its implementation in SURFEX v7.2. Geosciences Model Development 5, 773-791. https://doi.org/10.5194/gmd-5-773-2012.

Vionnet, V., Dombrowski-Etchevers, I., Lafaysse, M., Quéno, L., Seity, Y., Bazile, E. 2016. Numerical Weather Forecasts at Kilometer Scale in the French Alps: Evaluation and Application for Snowpack Modeling. Journal of Hydrometeorology 17, 2591-2614. https:// doi.org/10.1175/JHM-D-15-0241.1.

Watson, F.G.R., Anderson, T.N., Newman, W.B., Alexander, S.E., Garrott, R.A. 2006. Optimal sampling schemes for estimating mean snow water equivalents in stratified heterogeneous landscapes. Journal of Hydrology 328, 432-452. https://doi.org/10.1016/j. jhydrol.2005.12.032.

Winstral, A., Magnusson, J., Schirmer, M., Jonas, T. 2019. The Bias-Detecting Ensemble: A New and Efficient Technique for Dynamically Incorporating Observations Into PhysicsBased, Multilayer Snow Models. Water Resources Research 55, 613-631. https://doi. org/10.1029/2018WR024521.

Wipf, S., Stoeckli, V., Bebi, P. 2009. Winter climate change in alpine tundra: plant responses to changes in snow depth and snowmelt timing. Climatic Change 94, 105-121. https://doi. org/10.1007/s10584-009-9546-x. 
